\title{
Human Relations Training for Librarians?
}

$\mathrm{A}^{\mathrm{n}}$ FEW YEARs ago a great American educator stated that many colleges and universities are annually awarding degrees to "intellectual monstrosities" who can enumerate formulae in chemistry and physics by the score, who may call by name all the bones of the human frame, but who cannot give satisfactory answers to the following questions: "What is man? Who made him? What was he made for?"' Casselman was delivering a serious indictment of modern higher education. We suggest that the training of librarians may have to answer, in part at least, to the same indictment. To paraphrase the learned gentleman quoted above, we would say that each year our library schools are graduating intellectual characters who can enumerate the Dewey Decimal Classification System, who can recite all the titles from a bibliography course, who can even give out with the formulae for book budgets or the square footage requirements for a proposed building, but who cannot satisfactorily answer: What is man? Why does he act as he does? How should I respond to his actions? How can I work more effectively with him?

Our concern, then, is with the problem of translating the librarian's technical knowledge into personal modes of behavior which enable him to work more effectively with the reading public. We are not concerned with developing

\footnotetext{
1 Paul H. Casselman, "Philosophy, Human Relations, and Scientific Progress." School and Society, LXVII (1948), 9.
}

Mr. Anderson is Director of Libraries, Colorado State University; Dr. Kell is Associate Professor, Counseling Center, Michigan State University. more and better knowledge which may remain essentially within the librarian's head. We are concerned with the possibility that librarians can be better trained in ways of interpersonal interaction, which will more effectively put the librarian's knowledge in the service of the needs of the library patron.

Thirty years ago little could have been done or said which would have pointed toward a solution of the problem we have posed. Relatively little was known (except for a few pioneer thinkers) about the dynamics of human behavior, of the delicacies of interpersonal interaction, or of how people actually influence one another. In the past three decades the burgeoning fields of depth psychology, sociology, and other related disciplines have supplied a vast new knowledge of the nature of human personality and behavior. Along with this new knowledge has come the realization that people can be trained to influence one another in desirable directions, to communicate better, and to understand each other more fully.

Many applications of the new knowledge have been made in diverse and varied fields. Training techniques have developed rapidly. The classic experiment in human relations training in industry is now more than twenty years old. ${ }^{2}$ At the present time it is a rare company which does not spend a great deal of time and money in training a considerable proportion of its employees in more effective ways of interpersonal interaction among themselves and with others outside the company. Practical businessmen do not spend this time and

\footnotetext{
${ }^{2}$ Jules F. Roethlisberger and William J. Dickson, Management and the Worker (Cambridge, Mass.: Harvard University Press, 1939).
} 
money entirely because of altruistic motives. They spend because it pays off in higher production, higher employee morale, and more and better satisfied customers.

Industry is not alone in its application of the new knowledge. The various professions are becoming increasingly preoccupied with the nature of the human relationships between the doctor and patient, the lawyer and client, the teacher and student, the nurse and patient. The doctor is no longer simply trained in the diagnosis and treatment of disease. $\mathrm{He}$ is trained to take account of the individual characteristics of the patient, the psychological milieu in which the disease has occurred, the meaning of the disease to the patient, and, finally, the reactions of the patient to the doctor himself. The lawyer no longer simply interests himself in the client's legal problem, but in the client himself and the role he has played in creating the problem. The teacher no longer simply pours the multiplication table into a resistant receptacle. She works intelligently with a child who has understandable needs, aversions, and motivations which must be understood in order to work effectively with him. The nurse, too, is learning to deal with the patient as a person who has a disease rather than as a disease which happens to have a nuisance in the form of a person attached.

We are aware that good doctors, lawyers, teachers, nurses, and librarians, too, have probably always been able to take intelligent account of the all too human nature of their clientele. Our concern is that this important area is no longer being left to chance by other professions. Librarianship may be falling behind. Nor are we convinced that experience as a librarian is the sole possible answer. Twenty years of experience can be twenty years of learning, or it can be one year of experience repeated twenty times. We think that steps can be taken to insure that the librarian's training and work experience will continue to be learning experience.

By now the reader may be wondering what we are talking about in terms of concrete human relations situations in libraries. Are we talking about the need for librarians to be friendly? Yes, we are talking about friendliness, but we are also talking about something deeper and more fundamental. What are the attitudes of the librarian, conscious and otherwise, toward the patrons he serves? Are these attitudes communicated to the patron? What is the patron likely to learn from the interaction between the librarian and himself? What is the librarian likely to learn from this same situation?

Perhaps we can clarify what we are talking about and partially answer some of our questions by exploring a situation which probably occurs every day in libraries throughout the country. The participants in our situation are a college freshman taking his second semester of rhetoric and a reference librarian. Our freshman is like many a new college student. He is a bit brash, still a bit awed by it all, and more than a little frightened and confused by his assignment to do a research paper on a topic of his own choosing for his rhetoric course. Our librarian, on the other hand, has concluded, on the basis of his ten years of experience, that students usually ask stupid questions. What happens when these two have a brief encounter near the reference desk? We are inclined to think that the outcome will seldom be very good. The student asks a confused and tentative question of our librarian because he is confused and tentative. Our librarian pounces on the question and throws out a barrage: "Haven't you got a topic yet? or, how can you expect me to help you when you're so vague?" The student does battle for a minute or two and then retires in disorder with evi- 
dence to add to his fears that he may be an inadequate. Our librarian glows with satisfaction (inwardly, we hope) and chalks up another tally in support of his favorite hypothesis.

We will agree that our incident is perhaps a bit extreme but we are sure that such incidents do occur. We are also sure that a multitude of lesser and more subtle incidents occur in libraries every day. We think that librarians can learn to learn about patrons from such incidents and that such learning will lead to desirable modifications in many librarians' behavior.

How do we propose to go about promoting the kind of learning we have outlined? We suggest, principally, that a program of instruction be offered in library schools which has as its objective the analysis and understanding of incidents to which we have alluded. Who should teach such a course and how long should it be? We do not have the final answer. We know that most universities have qualified psychologists and sociologists who can give assistance in setting up such a course and who would, perhaps, be interested in teaching it. We think that such a course might profitably be a year in length. The first semester could comprise some grounding in the theory of human dynamics, classroom analysis of reported incidents such as we have described, analysis of tape recorded incidents, and the like. The second semester of work might be comprised principally of a practicum experience in which the student has experience of his own under the supervision of someone who can help him to analyze and to learn from his experience. The training of psychological counselors as well as the training of practitioners in other professions has developed along similar lines. ${ }^{3}$

${ }^{3}$ Carl Rogers, Client-Centered Therapy (Boston: Houghton Mifflin, 1951).

Elias H. Porter, An Introduction to Therapeutic Counseling (Boston: Houghton Mifflin, 1950).
In recommending such a course, we anticipate the cry from library educators that they have all the courses they can handle now. Perhaps this is so, but of what use are all the courses if the knowledge is not translated into effective relationships with library patrons? Nor, as we have indicated earlier, do we believe that experience will necessarily set everything right. We agree with Wallace Donham who says that the objective of every professional school is "to quicken the process of understanding experience and to prepare students for practice at constantly higher levels. ... When men are on their own, professional experience means more to them because of their training. The early understanding and the beginning of skills acquired in school are effective only in the sense that in the early period of practice young [people] can interpret their experience with more speed and effectiveness than they could without the orderly instruction and practice given in professional training." 4

We note that library school curricula provide at least some training in nearly every area of librarian job function. Training in dealing effectively with library patrons is conspicuous by its absence. Should such an important area continue to be left entirely to chance and the vicissitudes of experience? We don't think so. 4Wallace B. Donham, "An Experimental Course in
Human Relations in Harvard College," Journal of General Education, II (1947), 13.

(Editor's Note: Columbia University School of Library Service early recognized this problem in 1938. A course in this field was called "Psychological Adjustments," and was later revised and named "Applied Psychology for Librarians." Dr. Alice I. Bryan has been responsible for this field. In the revised curriculum in 1947 it was dropped for several years. The content was returned to the curriculum in the present revision, and, since the summer of 1957 , a course in "Interpersonal Relations" has been offered. It will be a part of the continuing program of the School. The title of the course in the future will be "Human Relations in Library Administration." The content of the field is included in the research program of the School, and one student has already embarked upon a doctoral dissertation.) 